\title{
TERAPI SUPORTIF KELUARGA MAMPU MENINGKATKAN KUALITAS HIDUP PASIEN GAGAL GINJAL KRONIS YANG MENJALANI HEMODIALISA
}

\author{
Virgianti Nur Faridah \\ Program Studi S1 Keperawatan STIKES Muhammadiyah Lamongan \\ Email : virgiantinff@yahoo.com
}

\begin{abstract}
Chronic renal failur is a dirsorder of renal function that is progressive and irreversibel, causing decreased kidneyfunction resulting in urea retention and other nitrogenous waste in the blood, the problem in this study of patients with chronic renal failure who underwent hemodialysis. The purpose of this study was to determine the effect of family supportive therapy on the quality of life of patients with chronic renal failur who underwent hemodialysis at the general hospital doctoral Soegiri Lamongan. Research using pre experiments using One Group Pretest-Posttest Design. By using technique random sampling. The population in this study amounted to 33 respondents, the sample in this study amounted to 30 respondents with chronic renal failure who underwent hemodialysis at the general hospital doktoral Soegiri Lamongan in march 2018. The data of this study were taken by using quality of life questionnaire WHOQOL-BREF. Analyzed using wilcoxon test with significance level $P<0,05$. The results showed prior to being given supportif therapy of life is (56,7\%), The quality of life is bad (36,7\%), And after the treatment of good quality of life (50\%), Medium quality of life (40\%),. Based on wilcoxon test results obtained $Z=-5,196^{a}$ value with the value of $P=$ 0,000 where $P$ 0,05. This shows that there is influence of supportif therapy to the quality of life of patients with chronic renal failure. Nurses can provide support for patient independence in lifestyle modification by involving the family's active role in improving the quality of life patients.
\end{abstract}

Keyword: Supportive Therapy, Chronic Kidney Disease, Quality Of Life

\section{PENDAHULUAN}

Gagal Ginjal Kronik (GGK) merupakan gangguan fungsi ginjal yang bersifat progresif dan irreversibel, menyebabkan penurunan kemampuan ginjal untuk mempertahankan metabolisme dan keseimbangan cairan maupun elektrolit, sehingga timbul gejala uremia berupa retensi urea dan sampah nitrogen lain dalam darah. Gagal ginjal kronik masih menjadi masalah besar di dunia. Gagal ginjal kronik sulit disembuhkan, biaya perawatan dan pengobatannya sangat mahal. Secara global lebih dari 500 juta orang mengalami gagal ginjal kronik (Smeltzer, 2008).

Berdasarkan data badan kesehatan dunia atau World Health Organization (WHO) memperlihatkan yang menderita gagal ginjal baik akut maupun kronik 
mencapai 50\% sedangkan yang diketahui dan mendapatkan pengobatan hanya $25 \%$ dan 12,5\% yang terobati dengan baik (Indrasari, 2015). Sedangkan menurut (Riskesdas tahun 2013) prevalensi gagal ginjal kronis berdasarkan diagnosis dokter di Indonesia sebesar 0,2\%. Prevalensi tertinggi di Sulawesi Tengah sebesar 0,5\%, diikuti Aceh, Gorontalo, dan Sulawesi Utara masing-masing 0,4\%. Sementara Nusa Tenggara Timur, Sulawesi Selatan, Lampung, Jawa Barat, Jawa Timur masingmasing 0,3\%, provinsi Sumatra Utara sebesar 0,2\%. Pada tahun 2011 di Indonesia terdapat 15.353 pasien yang baru menjalani Hemodialisa dan pada tahun 2012 terjadi peningkatan pasien yang menjalani Hemodialisa sebanyak 4.268 orang sehingga secara keseluruhan terdapat 19.621 pasien yang menjalani hemodialisa. Sampai akhir tahun 2012 sebesar 244 unit hemodialisis di Indonesia (Riskesdas, 2013).

Berdasarkan survey awal yang dilakukan peneliti di RSUD Dr. Soegiri Lamongan pasien gagal ginjal kronik yang menjalani hemodialisa pada tahun 2015 kurang lebih 138 pasien, meningkat pada tahun 2016 kurang lebih 323 pasien, pada tahun 2017 mulai pada bulan Januari sampai September kurang lebih 352 pasien, pengamatan awal yang peneliti lakukan terhadap 6 (enam) orang pasien pada Unit Hemodialisa RSUD Dr. Soegiri Lamongan, keenam orang pasien gagal ginjal kronik yang dijumpai tersebut, menunjukan adanya penurunan kualitas hidup terkait perubahan status kesehatan, fisik, psikologis, ekonomi dan sosial. Hampir semua mengalami kelemahan fisik yaitu adanya gangguan aktifitas sehari-hari, kurang tidur serta pembatasan intake nutrisi dan cairan yang harus dipenuhi. Hal ini juga menimbulkan beban psikologis seperti sedih, takut mati, cemas, putus asa, kecewa bahkan rendah diri. Disamping keluhan fisik dan psikologis juga muncul keterbatasan mereka dalam hubungan sosial dan lingkungan. Penyakit gagal ginjal kronik akan mengalami perubahan sosial, nutrisi merupakan komponen penting dan utama dalam kehidupan setiap orang. Untuk orang dengan gagal ginjal kronik pentingnya gizi mengingat dampak negatif dari manajemen diet yang buruk. Efek samping tersebut seperti hiperkalemia, hiperfosfatemia, protein yang berhubungan dengan kekurangan gizi dan kelebihan cairan. Sebagian besar dari interaksi sosial antara orang mellibatkan makan dan minum sehingga tidak jarang untuk pasien dengan gagal ginjal kronik untuk mengurangi keterlibatan sosial mereka karena pembatasan makanan dan cairan yang ketat.

Pasien gagal ginjal kronik tidak bisa disembuhkan sehingga kualitas hidup pasien menurun, penurunan kualitas hidup pada pasien gagal ginjal yang menjalani terapi hemodialisa akan menyebabkan komplikasi yang berkepanjangan, penurunan produktivitas dan perubahan mood negatif. Persepsi penderita tentang kualitas hidupnya yang semakin memburuk dapat memperberat kondisi penyakitnya (Togatorop, 2011). Kualitas hidup pasien Gagal Ginjal Kronis yang menjalani hemodialisa cukup menarik perhatian bagi profesional kesehatan, karena masalah kualitas hidup menjadi sangat penting dalam pemberian layanan keperawatan yang 
menyeluruh bagi pasien, dengan harapan pasien dapat menjalani hemodialisa dan mampu bertahan hidup walau dengan bantuan mesin dialisa (Bayhakki, 2013).

Terapi hemodialisa bagi penderita Gagal Ginjal Kronik merupakan upaya untuk mencegah kematian atau memperpanjang usia. Namun demikian, hemodialisa tidak dapat menyembuhkan atau memulihkan penyakit ginjal. Hemodialilsa juga tidak mampu mengimbangi hilangnya aktifitas metabolik atau endokrin oleh ginjal dan dampak dari gagal ginjal serta terapi terhadap kualitas hidup klien. Klien harus menjalani dialisis sepanjang hidupnya atau sampai mendapatkan ginjal baru melalui operasi pencangkokan. Untuk mendapatkan ginjal baru sangat sulit didapatkan karena masih banyak anggapan dari masyarakat bila tidak mempunyai salah satu ginjal akanmempengaruhi kondisi tubuh seseorang. Tindakan tersebut juga masih jarang terjadi di Indonesia (Smeltzer, 2008).

Terapi suportif merupakan alternatif pilihan terapi yang ditunjukan untuk meningkatkan kemampuan keluarga sebagai suport system. Suportive Group merupakan terapi yang diorganisasikan untuk membantu anggota saling bertukar pengalaman mengenai masalah tertentu agar dapat meningkatkan kopingnya. Suportive Group ditunjukan untuk mengurangi beban keluarga dan meningkatkan koping keluarga serta meningkatkan dukungan sosial. Maksud didirikannya supportive group adalah untuk memberikan dukungan. Fokus untuk pemulihan, aksi sosial termasuk kebijakan organisasi. Tujuan dan harapan dalam group adalah pengalaman kelompok yang positif. Tujuan penting adalah resolusi permasalahan dengan segera. Memberikan motivasi dan perubahan perilaku individu (Fadden, 1998, Wituk, dkk dikutip dalam Chien, dkk, 2006).

Hasil penelitian tentang terapi suportif banyak dilakukan diantaranya oleh Hernawati (2009) didapatkan peningkatan kemampuan kongnitif, afektif dan psikomotor keluarga. Hasil tersebut menunjukan bahwa kemampuan kelompok keluarga yang mendapatkan terapi suportif keluarga meningkat lebih tinggi secara bermakna dibandingkan dengan kelompok keluarga yang tidak mendapatkan terapi suportif keluarga. Terapi suportif keluarga ini masih direkomendasikan bagi keluarga yang mempunyai anggota keluarga yang sakit. Ini membuktikan pentingnya terapi suportif keluarga guna membangkitkan dan dukungan terhadap klien dan keluarga. Sehingga klien merasa diperhatikan oleh keluarga. Bagi keluarga juga mendapatkan pengetahuan bagaimana cara merwat anggota keluarga yang baik dan benar.

\section{METODE PENELITIAN}

Desain penelitian yang digunakan dalam penelitian ini adalah Pra Eksperiment dengan menggunakan desain One Group Pretest-Posttest Design. Dalam rancangan ini, tidak ada kelompok pembanding (kontrol) tetapi paling tidak dilakukan observasi pertama (pretest) yang memungkinkan peneliti dapat menguji 
perubahan-perubahan yang terjadi setelah adanya eksperimen (Notoatmodjo, 2010).

\section{HASIL PENELITIAN}

Tabel 1. Karakteristik Responden

\begin{tabular}{lcc}
\hline & Variabel & \multicolumn{2}{c}{ Frekuensi } \\
\cline { 2 - 3 } & n & \% \\
\hline Jenis kelamin & 12 & 40 \\
Laki-laki & 18 & 60 \\
Perempuan & & \\
Usia (tahun) & 2 & 6,7 \\
20-35 & 9 & 30 \\
35-45 & 19 & 63,3 \\
>45 & & \\
Pendidikan & 4 & 13,3 \\
Perguruan Tinggi & 6 & 20 \\
SMA & 13 & 43,4 \\
SMP & 7 & 23,3 \\
SD & & \\
Pekerjaan & 12 & 40 \\
Swasta & 10 & 33,4 \\
Petani & 1 & 3,3 \\
Buruh & 1 & 3,3 \\
PNS & 6 & 20 \\
Tidak Bekerja & & \\
\hline
\end{tabular}

Berdasarkan tabel 1 diatas menunjukan bahwa dari 30 pasien gagal ginjal kronik di ruang hemodialisa, sebagian besar berjenis kelamin perempuan 18 pasien (60\%), berusia diatas 45 tahun sejumlah 19 pasien $(63,3 \%)$, berpendidikan SMP sejumlah 13 pasien (43,3\%), dan bekerja sebagai swasta sejumlah 12 pasien (40\%).

\section{2) Data Khusus}

Tabel 2 Distribusi Pasien Berdasarkan Tingkat Kualitas Hidup Pre dan Post Terapi Supportif Pada Pasien Gagal Ginjal Kronik Di Ruang Hemodialisa RSUD Dr. Soegiri Lamongan.

\begin{tabular}{|c|c|c|c|c|c|}
\hline \multirow[b]{2}{*}{ No. } & \multirow[b]{2}{*}{ Tingkat Kualitas Hidup } & \multicolumn{4}{|c|}{ Terapi Supportif } \\
\hline & & $\begin{array}{c}\text { Sebelum Terapi } \\
\text { Supportif }\end{array}$ & $\%$ & $\begin{array}{c}\text { Sesudah Terapi } \\
\text { Supportif }\end{array}$ & $\%$ \\
\hline 1. & Sangat buruk & 2 & $6.6 \%$ & 0 & $0 \%$ \\
\hline 2. & Buruk & 11 & $36.7 \%$ & 3 & $10 \%$ \\
\hline 3. & Sedang & 17 & $56,7 \%$ & 12 & $40 \%$ \\
\hline 4. & Baik & 0 & $0 \%$ & 15 & $50 \%$ \\
\hline 5. & Sangat baik & 0 & $0 \%$ & 0 & $0 \%$ \\
\hline & Jumlah & 30 & $100 \%$ & 30 & $100 \%$ \\
\hline & $\rho=0.000$ & dan & &, 05 & \\
\hline
\end{tabular}


Berdasarkan tabel 2 diatas dapat diketahui bahwa terdapat perubahan kualitas hidup yaitu 30 pasien (100\%), setelah diberikan terapi supportif terjadi perubahan peningkatan kualitas hidup. Sebagian besar pasien yang berubah menjadi kualitas hidup baik sejumlah 15 pasien (50\%), hampir sebagian pasien yang dulunya memiliki kualitas hidup buruk berubah ke kualitas hidup sedang sejumlah 12 pasien (40\%), dan hanya sebagian kecil pasien yang masih memiliki kualitas hidup buruk sejumlah 3 pasien $(10 \%)$.

Berdasarkan hasil pengujian dengan uji wicoxon didapatkan nilai $\mathrm{Z}=-5,196^{\mathrm{a}}$ dan $\mathrm{p}=0,000$ dimana hal ini berarti $\mathrm{P}$ sign $<0,05$ sehingga $\mathrm{H} 1$ diterima artinya ada pengaruh terapi supportif keluarga terhadap kualitas hidup pasien gagal ginjal kronik yang menjalani hemodialisa di RSUD Dr. Soegiri Lamongan Tahun 2018.

Tabel 2 menunjukan bahwa dari 30 pasien yang diteliti, sebagian besar memiliki tingkat kualitas hidup sedang yaitu sejumlah 17 pasien $(56,7 \%)$, kemudian yang memiliki kualitas hidup buruk yaitu sejumlah 11 pasien $(36,7 \%)$, dan sebagian kecil yang memiliki kualitas hidup sangat buruk yaitu sejumlah 2 pasien $(6,6 \%)$.

Menurut Supriyadi, Wagio (2011), yang menyatakan bahwa kualitas hidup pasien yang menjalani hemodialisa berada pada tingkatan sedang yakni 16 pasien (53,3\%), sebelum dilakukan HD dan meningkat pada tingkatan kualitas hidup tinggi setelah menjalani hemodialisa, akan tetapi dari masing-masing responden berbeda nilainya. Hal ini sesuai dengan pernyataan Suhud (2009) bahwa pasien gagal ginjal kronik akan mempunyai ketergantungan akan terapi hemodialisa secara rutin untuk mempertahankan kualitas hidupnya.

Menurut Townsen, (2009) terapi supportif merupakan suatu bentuk terapi yang terprogram waktu dengan baik (Time Limited Program). Maksudnya adalah proses pelaksanaan terapi dapat berjalan beberapa minggu sampai bulan. Pada pelaksanaannya teori ini sangat mendukung pelaksanaan terapi supportif yang dilaksanakan peneliti pada keluarga yang merawat klien gagal ginjal kronik yang menunjukan adanya kesamaan sesuai dengan diawal perencanaan terapi ini akan dilakukan dalam 2 kali pertemuan dalam seminggu.

Berdasarkan hal tersebut maka dapat disimpulkan bahwa dukungan keluarga sangat berpengaruh terhadap kesehatan mental anggota keluarganya, sikap, tindakan dan penerimaan keluarga terhadap anggota yang sakit. Aspek kesehatan dan support keluarga akan berpengaruh terhadap kualitas hidupnya pasien gagal ginjal kronik yang menjalani hemodialisa di RSUD Dr. Soegiri Lamongan.

Tabel 2 menunjukan bahwa dari 30 pasien yang diteliti, setelah dilakukan terapi supportif pasien yang menjalani terapi hemodialisa memiliki tingkat kualitas hidup baik yaitu sejumlah 15 pasien (50\%), yang memiliki kualitas hidup sedang yaitu sejumlah 12 pasien (40\%), dan yang memiliki kualitas hidup buruk yaitu sejumlah 3 pasien $(10 \%)$.

Meningkatnya kualitas hidup pasien gagal ginjal kronik yang menjalani hemodialisa dipengaruhi beberapa faktor salah satunya adalah faktor pemahaman 
pasien tentang penyakitnya. Support dari keluarga merupakan salah satu peran penting dalam menunjang perubahan perilaku, meningkatkan pemahaman pasien tentang penyakitnya, sehingga tercapai kesehatan yang optimal, penyesuaian keadaan psikologis dan peningkatan kualitas hidup Penyakit yang diderita, pengobatan yang dijalani dapat mempengaruhi kapasitas fungsional pasien gagal ginjal kronik yang didefinisikan sebagai kualitas hidup (Quality of Lifel QOL) (Soegondo dkk, 2009).

Terapi supportif keluarga merupakan kelompok masyarakat kecil, masingmasing anggota mendapatkan kesempatan melakukan praktek dalam kelompok sehingga mereka melakukan perilaku sesuai contoh dan merasakan emosi yang menyertai perilaku, masing-masing anggota kelompok saling memberi umpan balik, pujian dan dorongan, klien merasakan adanya persamaan yaitu klien sadar bahwa ada pasien lain yang mengalami masalah yang serupa dengan dirinya sehingga meningkatkan pembukaan diri dan memotivasi untuk berubah Townsen (2009).

Berdasarkan hasil penelitian dan teori diatas dapat disimpulkan bahwa terapi supportif dapat meningkatkan kualitas hidup pasien gagal ginjal kronik yang menjalani hemodialisa. Terapi supportif merupakan terapi psikoterapi yang ditunjukkan kepada klien baik secara individu maupun secara berkelompok. Terapi supportif merupakan bentuk terapi kelompok yang dapat dilakukan pada berbagai situasi dan kondisi diantaranya pada klien dengan masalah kualitas hidup, kelompok supportif merupakan sekumpulan pasien-pasien yang berencana, mengatur dan berespon secara langsung terhadap isu-isu dan tekanan khusus maupun yang merugikan. Tujuan awal dari kelompok ini adalah memberikan support dan menyelesaikan pengalaman hemodialisa dari masing-masing pasien.

Tabel 2 diatas juga menginformasikan bahwa terdapat perubahan kualitas hidup yaitu 30 pasien (100\%), setelah diberikan terapi supportif terjadi perubahan peningkatan kualitas hidup. Lebih dari sebagian pasien sejumlah 15 pasien (50\%) memiliki tingkat kualitas hidup baik, pasien yang dulunya memiliki kualitas hidup buruk berubah ke kualitas hidup sedang sejumlah 12 pasien (40\%), dan hanya sebagian kecil pasien yang masih memiliki kualitas hidup buruk sejumlah 3 pasien (10\%). Dengan demikian dapat disimpulkan bahwa hasil dari penelitian ini menunjukan bahwa ada pengaruh terapi supportif keluarga terhadap kualitas hidup pasien gagal ginjal kronik yang menjalani hemodialisa di RSUD Dr. Soegiri Lamongan.

Hal ini dapat dibuktikan dengan hasil analisis data menggunakan Statistical Product and Service Solution (SPSS) Ver. 16 dengan uji wicoxon didapatkan nilai $\mathrm{Z}=-5,196^{\mathrm{a}}$ dan $\mathrm{p}=0,000$ dimana hal ini berarti $\mathrm{P}$ sign $<0,05$ sehingga $\mathrm{H} 1$ diterima artinya ada pengaruh terapi supportif keluarga terhadap kualitas hidup pasien gagal ginjal kronik yang menjalani hemodialisa di RSUD Dr. Soegiri Lamongan Tahun 2018 . 
Kualitas hidup pasien gagal ginjal kronik yang menjalani terapi hemodialisa masih merupakan masalah yang menarik perhatian para profesional kesehatan. Kualitas hidup pasien yang optimal menjadi isu penting yang harus diperhatikan dalam memberikan pelayanan keperawatan yang komperhensif. Pasien bisa bertahan hidup dengan bantuan mesin hemodialisis, namun masih menyisakan sejumlah persoalan penting sebagai dampak dari terapi hemodialisa. Dukungan keluarga adalah sikap, tindakan dan penerimaan keluarga terhadap penderita yang sakit. Keluarga juga berfungsi sebagai sistem anggotanya dan anggota keluarga memandang bahwa pasien yang bersifat mendukung selalu siap memberi pertolongan dengan bantuan jika diperlukan (Friedman, 2010).

Support keluarga adalah dukungan verbal dan non verbal, saran, bantuan yang nyata atau tingkah laku yang diberikan oleh pasien-pasien yang akrab dengan subjek di dalam lingkungan sosialnya atau berupa kehadiran dan hal-hal yang dapat memberikan keuntungan emosional atau berpengaruh pada tingkah laku penerimanya (Gottlieb, (1998) dalam Ali, (2009)).

Berdasarkan hal tersebut, maka dapat disimpulkan bahwa terapi supportif keluarga memiliki pengaruh yang cukup bermakna dalam perubahan kualitas hidup pasien gagal ginjal kronik. Dengan kata lain bahwa terapi supportif dapat meningkatkan kualitas hidup pasien gagal ginjal kronik yang menjalani hemodialisa di RSUD Dr. Soegiri Lamongan.

\section{KESIMPULAN DAN SARAN}

Kesimpulan yang diambil dari penelitian ini adalah :

1. Hampir setengah pasien gagal ginjal kronik yang menjalani hemodialisa di RSUD Dr. Soegiri Lamongan mengalami kualitas hidup sedang 17 pasien $(56,7 \%)$, sebelum diberikan terapi supportif keluarga.

2. Hampir setengah pasien gagal ginjal kronik yang menjalani hemodialisa di RSUD Dr. Soegiri Lamongan mengalami kualitas hidup baik 15 pasien (50\%), setelah diberikan terapi supportif keluarga.

3. Ada pengaruh terapi supportif keluarga terhadap kualitas hidup pada pasien gagal ginjal kronik yang menjalani hemodialisa di RSUD Dr. Soegiri Lamongan Tahun 2018.

Selanjutnya dari hasil penelitian, peneliti mengharapkan penelitian ini dapat dijadikan sebagai masukan kepada perawat untuk memberikan intervensi keperawatan berupa terapi supportif keluarga yang dapat meningkatkan kualitas hidup pasien gagal ginjal kronik yang menjalani hemodialisa..

DAFTAR PUSTAKA

Ali, Z. (2009). Pengantar Keperawatan Keluarga. Jakarta: EGC.

Bayhakki. (2013). Seri Asuhan Keperawatan Klien Gagal Ginjal Kronik. Jakarta: EGC. 
Chien, W.T., Chan., S.W.C., dan Thompson, D.R.(2006). Effects of a mutual support group for families of Chinese people with scizophenia: 18-Months follow-up. Januari 2, 2011. http://bip.rcpsych.org

Friedman. M. (2010). Buku Ajar Keperawatan Keluarga: Riset Teori dan Praktek. Edisi ke 5. Jakarta: EGC.

Hernawati, T. (2009). Pengaruh Terapi Suportif Terhadap Kemampuan Keluarga Dalam Merawat Klien Gangguan Jiwa di Kelurahan Sindang Barang Bogor tahun 2008. FIK-UI. Tesis tidak dipublikasikan

Indrassari, Denita Nur. (2015). Perbedaan Kadar Ureum dan Kreatinin. Yogyakarta

Notoatmojo.S. 2010.Metodologi Penelitian Kesehatan. Rineke Cipta Jakarta

Riskesdas. (2013). Laporan Nasional Riskesda 2013. http://litbag.depkes.go.id/ Diakses tanggal 01 Oktober 2014

Smeltzer, S. S. (2008). Buku Ajar Keperawatan Medikal Bedah . Jakarta: EGC.

Soegondo, dkk. (2009). Penatalaksanaan Diabetes Mellitus Terpadu. Jakarta. Fakultas Kedokteran Universitas Indonesia.

Suhud, Mohammad. (2009). Apakah Itu Kualitas Hidup. Diakses dari http://www.ygdi.org/foto_prod/upload_pdf/769design\%20dialife_april\% 2009.pdf pada tanggal 2 juli 2014

Supriyadi, Wagio \& Widowati, S. R. (2011). Tingkat Kualitas Hidup Pasien Gagal Ginjal Kronik Terapi Hemodialisis. KEMAS,107-112.

Togatorop, L. (2011). Hubungan Perawat Pelaksana Dengan Kualitas Hidup Pasien Gagal Ginjal Kronik Yang Menjalani Hemodialisa. Medan

Towsend, M. C. (2009). Psychiatric Mental Healt Nursing Concept Of Care In EvidenceBased Practice. Ed.6. Philadephia F.A. Davis Company 